\title{
The Role of Teacher Professionalism in Improving the Quality of Education at the First Middle School Level
}

\author{
Anwar Bay ${ }^{1 *}$, Edi Harapan ${ }^{2}$
}

\author{
${ }^{1}$ SMPN 2 Sumber Marga Telang \\ ${ }^{2}$ Universitas PGRI Palembang \\ *Corresponding author.Email: Anwarbay11@gmail.com
}

\begin{abstract}
This study aims to determine and describe the role of professionalism of teachers in planning learning, implementing learning, evaluating learning in improving the quality of education in junior high schools in Sumber Marga Telang District, Banyuasin Regency, the obstacles faced by teachers in planning learning, implementing learning, evaluating learning in improving the quality of education. and strategies for planning lessons, implementing learning, evaluating learning in improving the quality of education in schools. This research is qualitative research with a descriptive approach. The data sources of this research are from the principal and teachers. Data collection techniques were obtained from: (1) observation; (2) interview; and (3) documentation. The results of this study were obtained: (1) it can be said that they play an active role, where the teacher plans in advance in preparing the lesson plans, in carrying out the learning according to the established curriculum; (2) The obstacles faced include the lack of learning resources as a supporting medium for teachers in delivering learning so that the learning process that is delivered does not run as expected and is less than optimal; (3) The strategy is carried out by discriminating the ability of teachers and utilizing minimal learning resource.
\end{abstract}

Keywords: Teacher, Professionalism, Quality of Education

\section{INTRODUCTION}

According to Law Number 20 the Year 2003 Article 1, education is a conscious and planned effort to create an atmosphere for the learning and learning process. Meanwhile, the national education is education based on Pancasila and the 1945 Constitution of the Republic of Indonesia which is rooted in religious values, Indonesian national culture, and responsive to the demands of changing times.

The progress of a nation is very much determined by the quality of its resources, both natural resources, artificial resources, and human resources. The quality of human resources can be realized by a good educational process and from quality educational institutions.

The development and improvement of the quality of school education require synergy from all school education stakeholders in supporting their effective implementation. Many experts say that "The quality of education in Indonesia is of great concern." This can be proven from a survey issued by the Political and Economic Risk Consultant (PERC), where the quality of education in Indonesia ranks 12th out of 12 countries in Asia. This position places the quality of education in Indonesia below Vietnam.

Improving the quality of education is closely related to efforts to increase the professional maturity of teachers who will be able to anticipate challenges in the world of education. In Government Regulation Number 19 of 2005 concerning National Education Standards, Article 28 Paragraph 1 states that educators must have competencies that include: pedagogical, personal, professional, and social. Professional teachers are the key to fluency and success in the learning process in schools. Because only professional teachers can create active situations for students in learning activities.

Marlina et.al. argues that " Professional teachers must have teacher competence which is obtained through teacher education such as (Bachelor Degree of Elementary School Teacher, Bachelor Degree of Education, and Education certificate) which are obtained and special education for that field [1]. Teacher competence is obtained through what is called professionalization which is carried out both before a person undergoes that profession (preservice 
training or pre-position) or after undergoing a profession (in-service training). "

In the Government Regulation (PP) No. 19 of 2005 in Kurniasih, professional teachers should have four competencies, namely 1) pedagogical, 2) personality, 3) social, and 4) professional [2]. Therefore, the teachers who have competencies are expected to be able to direct and develop the potential of their students and easily overcome the learning difficulties faced by these students.

Based on the preliminary data through observations at SMP Negeri 1 Sumber Marga Telang, Banyuasin Regency, the learning process carried out was assisted by several teachers teaching, namely 17 teachers, consists of 2 civil servant teachers and 15 noncivil servant teachers. The teacher planned the lesson is in line with the 2013 curriculum, but in the implementation of learning sometimes it does not accompany teaching aids. The teacher in carrying out the learning should accompany teaching aids so that students can understand the material presented. Besides that, the teaching aids at SMP Negeri 1 Sumber Marga Telang, Banyuasin Regency are still very limited, with the lack of teaching aids so that teachers in implementing learning are not optimal.

It was also explained that not all the teachers at SMP Negeri 1 Sumber Marga Telang, Banyuasin Regency who have a disciplined background in line with the subject being taught. Of the 17 existing teachers, 5 are non-linear teachers. Teachers are also in carrying out their duties, sometimes their attendance is not by the set time. The teacher should have attended first so that the learning process can be effective. Teachers in conducting learning evaluations based on allocation provisions on a scheduled basis, namely every mid-semester, per semester, and at the end of the year (final school exams). Evaluation should be done at any time during the learning process, such as evaluating daily tests.

The teachers gave remedial to students who get scores below the standard of KKM, and it can be explained at apperception and help students who have difficulty learning so that from this help students can understand the difficulties they experience. Besides that, the teacher does not guide students, it should be from the evaluation carried out that the targets that must be achieved in improving the learning outcomes of these students can be seen, such as giving assignments in the form of homework and other tasks so that students can learn. independently or in groups. The information obtained was also added, that of the 2 civil servant teachers, these were not certified.

The relevant research strengthens the case of this study, as research by Research Sianturi et. al. concluded that the chief strategy in developing a competent of professionals are teachers assigned to participate in education and training, either reply carried out by the school institution itself and by other educational institutions [3]. Then, the teacher is asked to train and develop himself related to his job or position such as discipline, discussion, and motivation. Besides, the principal also completes school infrastructure. In this study, the researcher concludes that there are similarities and differences between previous researchers and current research, namely both researching teacher professionalism. Whereas the difference between previous research and current research is that the current research examines the role of teacher professionalism in improving the quality of education in junior high schools in Sumber Marga Telang District, Banyuasin Regency.

Muslim et.al. states that the principal's leadership includes aspects, a) ways of communicating; b) giving motivation; c) leadership skills; d) decision making; and e) positive power is in the very good category [4]. The quality aspect of education is based on Government Regulation Number 19 of 2005 concerning eight well-implemented National Education Standards. This study has similarities and differences with current research, namely both assessing the quality of education. The difference is that the current research examines the role of teacher professionalism in improving the quality of education in junior high schools. Yuliandri and Tahrun study explain that there are some positive effects with the existence of Teacher Professional Allowances (TPG) on increasing teacher competence at SD Negeri 3 Rambutan Banyuasin [5].

The purpose of this study was to identify and describe: (1) The professional role of teachers in planning learning, implementing learning, evaluating learning in improving the quality of education in junior high schools in Sumber Marga Telang District, Banyuasin Regency ; (2) Obstacles faced by teachers in planning learning, implementing learning, evaluating learning in improving the quality of education in junior high schools in Sumber Marea Telang District, Banyuasin Regency; (3) S Strategy that teachers plan learning, implementing the learning, evaluate learning in improving the quality of education in Junior High School in the District Resource Marga Telang Banyuasin.

A role is an attitude or behavior expected by many people or a group of people towards a person or group that has a certain status and position. When associated with the professional role of teachers, the role is not only an individual right and obligation but is a duty and authority that the teacher has, such as its role in improving the quality of education at the junior high school level which is the main task and function of the teacher itself.

According to Bafadal, professional teachers are teachers who can manage themselves in carrying out daily tasks. professional teachers are teachers who have the competencies required to carry out educational and teaching tasks [6]. Further 
Based on the description above, the authors conclude that teacher professionalism is a field of work that is owned by someone who has taken a level education (Junior High School, Diploma-III, Bachelor Degree, Master Degree, and Doctoral Degree).

\section{METHODS}

This research is qualitative research which refers to qualitative research, which is presented according to its stages, namely: (1) Pre-field Stage, (2) Field Activity Stage, and (3) Post-field Stage [7]. In the pre-field stage, the researcher proposes a research proposal on the role of teacher professionalism in improving the quality of education at SMP in Sumber Marga Telang District, Banyuasin Regency. The proposal was submitted with, approval and permission of the supervisor. Because in the qualitative approach, the research proposal is considered to be tentative. Therefore, the seminar opportunity is used to capture criticism and input, both on the topic and research methods. Based on these criticisms and input, the researcher fixed the design of this study and carried out a field assessment. In the field research implementation stage, the researcher prepared an interview sheet aimed at the respondents, namely the teachers who taught at SMP Negeri 1 Sumber Marga Telang District, Banyuasin Regency. Through interviews, researchers seek to obtain information by physically meeting face to face and questioning with informants. With this technique, the researcher acts as a data collection tool. In the post-field stage, after the data has been collected, filtering or selecting the appropriate data to be presented in the research report. The collected data is reduced and presented then verified as a research report. The certainty of this research is pursued by taking into account the support of field data records and the internal coherence of research reports. This is done by way of asking the various parties to audit the correspondence between the findings with the data acquisition and research methods. Dependency research is pursued by dependency audits. In this case, the researcher provides research results and reports the research process including the "traces" of the activities used. Based on his search, whether the research findings have relied on the results in the field. Arikunto argues that in a study data is needed. In data collection techniques are needed, both techniques in providing data, and techniques in classifying the data that has been collected [8]. Data collection methods in this study include observation, interviews, and documentation. The data analysis technique consists of three stages, namely: data reduction, display or presentation of data as well as drawing conclusions and data verification [9]. There are four types of data validity criteria, namely: (1) creditability; (2) transferability; (3) dependability; and (4) confirmability.

\section{RESULTS AND DISCUSSION}

Based on the observation of the research that the role of the professionalism of teachers in improving the quality of education at secondary school level first at the District Resource Marga Telang Banyuasin, namely at SMP Negeri 1 Source Marga Telang, it is known that the teachers through its role have been trying to improve education by means abide by the rules at SMP Negeri 1 Sumber Marga Telang, Banyuasin Regency. Besides, the teachers have tried to plan to learn according to the established curriculum, carry out the best possible learning, although it can be said that the supporting learning resources available at SMP Negeri 1 Sumber Marga Telang are still inadequate. The teacher has evaluated the learning results that have been delivered, both evaluations are carried out in the middle of the semester when the exam learning process has been carried out, evaluating each semester and conducting an evaluation at the end of the learning activities that have been implemented. The teacher has followed up on the learning results delivered, such as providing remedial to students who have scores below the KKM and providing enrichment.

Based on the research data obtained, it can be explained that the role of teacher professionalism in improving the quality of education at the junior high school level in Sumber Marga Telang District, Banyuasin Regency, namely at SMP Negeri 1 Sumber Marga Telang, Banyuasin Regency, is described as follows.

\section{The Role of Teacher Professionalism in Improving the Quality of Education}

Based on the observation of the study, the role of the professionalism of teachers in improving the quality of education at secondary school level first at the District Resource Marga Telang Banyuasin, namely in SMP Negeri 1 Source Marga Telang, it is known that the teachers through its role have been trying to improve education by means abide by the rules at SMP Negeri 1 Sumber Marga Telang, Banyuasin Regency. Also, teachers have tried to plan to learn according to the established curriculum, carry out the best possible learning, although it can be said that the supporting learning resources available at SMP Negeri 1 Sumber Marga Telang are still inadequate.

The role of teacher professionalism in improving the quality of education at the junior high school level in Sumber Marga Telang District, Banyuasin Regency, namely at SMP Negeri 1 Sumber Marga Telang refers to the implementation of the curriculum that must be implemented by referring to the following: (1) Developing a balance between developing spiritual attitudes and social, curiosity, creativity, cooperation with intellectual and psychomotor abilities; (2) The school is part of the community that provides a planned learning 
experience where students apply what they learn at school to the community and utilize the community as a learning resource; (3) Developing attitudes, knowledge, and skills and applying them in various situations in schools and communities; (4) Allow sufficient time to develop various attitudes, knowledge, and skills; and (5) Competence is expressed in the form of class core competencies which are further detailed in the basic competencies of the subjects.

The learning process that was based on the above principles must be consciously created by the teacher for the achievement of Graduate Competency Standards. The learning approach following the principles above is the approach of contextual learning which has seven main components of learning, namely : (1) constructivism, (2) ask (questioning), (3) investigating (inquiry), (4) community learning, (5) modeling, (6) reflection, and (7) authentic assessment. These contextual learning approaches will facilitate the strengthening of scientific thinking processes. The Contextual Learning Approach that strengthens this scientific thinking process will result in active student learning that integrates character education.

The results of this study are supported by several theories that become the reference for this study as stated that it is the teacher who directly deals with students to transfer knowledge and technology as well as to educate by positive values through guidance and the example that has no equal. The existence of teachers in education is very crucial because the obligation is not only to transfer knowledge but also to internalize the values to participants. Professional competence is the ability to master learning materials broadly and deeply which includes: 1) concepts, structures, and scientific/technological/artistic methods that cover/are coherent with teaching materials; 2) teaching materials in the school curriculum; 3) the conceptual relationship between related subjects; 4) application of scientific concepts in everyday life; and 5) professional competition in a global context while preserving national values and culture [6].

This was confirmed by the principal of SMP Negeri 1 Sumber Marga Telang based on the results of the interview who said:

"I have tried to develop the existing curriculum and refer to the 2013 curriculum"

\section{Obstacles Faced by Teachers in Planning, Implementing, And Learning}

The obstacles faced by teachers in improving the quality of education in Junior High Schools in Sumber Marga Telang District, Banyuasin Regency include the lack of learning resources as a supporting medium for teachers in delivering learning, so that the learning process that is delivered does not go as expected and is less than optimal. In addition, improving the quality of education is still constrained by teachers who do not have an educator certificate, because the teacher's discipline does not meet the competency test requirements, because their educational background is not Bachelor Degree.

This is supported by the results of interview with teachers at SMP Negeri 1 Sumber Marga Telang who said:

"Teachers at SMP Negeri 1 Sumber Marga Telang in delivering learning materials are in accordance with the curriculum. Furthermore, the class VII homeroom teacher added an explanation that generally the things that become obstacles in delivering learning material to students are constrained by the learning media (learning facilities) available in school so that the class VII homeroom mother in delivering learning material is not supported by adequate learning resources.

In line with the description above, Kurniasih argues that good teacher competence can contribute to the world of education, considering that teachers are a vital component [2]. Teachers who play a role in transforming knowledge even though they are recognized in an increasingly sophisticated era, teachers are not the only source of knowledge. However, at the level of basic education, the teacher still plays a role. In other words, teachers are the key to educational success.

\section{Strategies Undertaken by Teachers in Planning, Implementing and Learning}

Based on the observation of the research, a strategy that teachers in improving the quality of education in Junior High School in the District Resource Marga Telang Banyuasin by way to empowerment the ability of teachers and utilize the facility of learning resources roughing strategy provide examples related to the daily lives of learners in the real world related to the learning material presented. Besides that, the teacher also tries to add insight so that the professionalism of the teacher can be even better. The implementation of the learning delivered refers to active, innovative, creative, effective, and fun learning.

From interviews with teachers at SMP Negeri 1 Source Marga Telang as saying:

"Teachers in implementing learning use active, innovative, creative, effective and fun learning strategies".

The learning process that was carried out by teachers at SMP Negeri 1 Sumber Marga Telang, Banyuasin Regency refers to the established curriculum and at SMP Negeri 1 Sumber Marga Telang, Banyuasin Regency, tries to realize the goals of education in schools, namely, as follows. (1) The implementation of religious activity programs such as: reading Yasiin, Istighosah, Ramadhan class and commemoration of religious holidays; 
Implemented curriculum development covering 8 educational standards; (3) the implementation of Active, Innovative, Creative, Effective, and Fun learning with a contextual approach; (4) Achievement of achievements in academic and nonacademic competitions at the regency / provincial level; (5) The implementation of $5 \mathrm{~S}-1 \mathrm{P}$ habituation (Greetings, Salim, Smile, Greetings, Courtesy, and Care for the Environment; and (6) Realizing the character of school members who have a noble character, clean from drugs through habituation programs, $7 \mathrm{~K}$ program activities.

\section{CONCLUSION}

Based on the results of the research, it can be concluded as follows: (1) The role of teacher professionalism in improving the quality of education in Junior High Schools in Sumber Marga Telang District, Banyuasin Regency can be said to play an active role, where teachers plan in compiling lesson plans, in implementing learning under The curriculum is determined and refers to the Indonesian Minister of Education and Culture, where the educational process leads to a character approach using a contextual approach. Furthermore, the teacher always evaluates the learning outcomes in the middle of each semester, per semester (odd and even semesters); (2) The obstacles faced by teachers in improving the quality of education at junior high schools in Sumber Marga Telang District, Banyuasin Regency include the lack of learning resources as a supporting medium for teachers in delivering learning so that the learning process delivered does not go as expected and less than optimal; (3) The strategy carried out by teachers in improving the quality of education at junior high schools in Sumber Marga Telang District, Banyuasin Regency by empowering teachers' abilities and utilizing makeshift learning resource facilities with a strategy of providing examples related to the daily lives of students in the world real related to the learning material presented. Besides that, the teacher also tries to add insight so that the professionalism of the teacher can be even better. The implementation of the learning delivered refers to active, innovative, creative, effective, and fun learning.

Based on the conclusions that have been stated above, the suggestions that can be given in this study are as follows; (1) Principals should always pay attention to teachers so that they can improve their professionalism in teaching and help seek teachers who do not have an educator certificate; (2) For teachers, they should always improve their professionalism in teaching, such as adding scientific insight through education and training, attending seminars, especially for teachers who do not have an educator certificate in order to strive for existing deficiencies ; in the end, they will be able to take the teacher competency test and obtain certification; and (3) For the District Education and Culture Office, it should be able to further increase attention to schools, especially schools in Sumber Marga Telang, Banyuasin Regency to provide assistance in the form of facilities and infrastructure such as teaching aids as a source of learning so that the quality of education could be better.

\section{REFERENCES}

[1] Kristiawan, M., Safitri, D., \& Lestari, R. (2017). Manajemen Pendidikan. Yogyakarta: Deepublish.

[2] Kurniasih, I. (2017). Kompetensi Pedagogik, Teori dan Praktik Untuk Peningkatan Kinerja dan Kualitas Guru. Jakarta: Kata Pena.

[3] Sianturi., Lian, B. \& Puspitasari Y. (2020). Strategi Kepala Sekolah dalam Mengembangkan Kompetensi Profesional Guru. Jurnal Pendidikan Tambusai. Vol. 4 No. 3, 1836-1839. https://jptam.org/index.php/jptam/article/view/6 54

[4] Muslim B, Harapan, \& E. Kesumawati, N. (2020). Kepemimpinan Kepala Sekolah dalam Meningkatkan Mutu Pendidikan di SMA Negeri 1 Indralaya Selatan. Jurnal Intelektualita: Keislaman, Sosial, dan Sains. Vol. 9, No. 1. http://jurnal.radenfatah.ac.id/index.php/intelektu alita.

[5] Yuliandri., \& Tahrun. (2017). Tunjangan Profesi Sebagai Upaya Peningkatan Kompetensi Guru Untuk Mewujudkan Guru Profesional. Jurnal Manajemen, Kepemimpinan, dan Supervisi Pendidikan. Vol. 2 No. 1, 115-127. https://jurnal.univpgri-palembang.ac.id/index. php/JMKSP/article/view/1159

[6] Bafadal, I. (2014). Peningkatan Profesionalisme Guru dalam Kerangka Manajemen Peningkatan Mutu Berbasis Sekolah. Jakarta: Bumi Aksara.

[7] Sukmadinata, N. S. (2015). Metode Penelitian Pendidikan. Bandung: Remaja Rosdakarya.

[8] Arikunto, S. (2010). Prosedur Penelitian Suatu Pendekatan Praktek. Edisi Revisi. Jakarta: Rineka Cipta. 